Egyptian Journal of Aquatic Biology \& Fisheries

Zoology Department, Faculty of Science,

Ain Shams University, Cairo, Egypt.

ISSN $1110-6131$

Vol. 23(3): 185 - 194 (2019)

www.ejabf.journals.ekb.eg

\title{
Histological Assessment of Gonadal Alteration in Wild Nile Tilapia Oreochromis niloticus Inhabiting Lake Manzala, Egypt
}

\author{
Amer, M.A. and Ahmed, K.M. \\ Animal Production Department, Faculty of Agriculture, Ain Shams University, \\ P.O. Box 68, Hadayek Shubra, 11241, Cairo, Egypt. \\ Corresponding author: amer_fish@yahoo.com
}

\begin{abstract}
ARTICLE INFO
Article History:

Online: July 15, 2019

Keywords:

Lake Manzala

Pollutants

O. niloticus

Testis

Ovary

Histology
\end{abstract}

Received: June 17, 2019

Accepted:July 12, 2019

\begin{abstract}
The aim of the study was to detect the detrimental effects of water pollutants on gonads structure of wild tilapia, O. niloticus. A total of 209 wild fish were collected from Lake Manzala during the spawning season, summer of 2018. According to the sex ratio and the body weigh fish were divided into four male and three female groups. Anatomical measurements and histological examination were performed for all specimens. Data reveled that sex ratio of collected fish was 74.64 and 25.36 for male and female, respectively. Body length for males was ranged from 11.6 to 19.5 $\mathrm{cm}$ and from 13.6 to $18.58 \mathrm{~cm}$ for females. Body weight was ranged from 30.05 to $139.73 \mathrm{~g}$ and from 39.60 to $125.13 \mathrm{~g}$ for male and female, respectively. Microscopic inspection illustrated that fish gonads both testes and ovaries were affected as indicated by the deterioration and degeneration of seminiferous tubules and germinal epithelium as well as the existent of testis-ova and testis fibrosis, and in female by increasing the percentage of atretic follicles and reabsorption of vitellogenic oocytes. The data reflected the prominent changes in male and female gonadal structure, which could be attributed to the accumulation of pollutants and prolonged period of exposure. This may affect the future spawning seasons; the rate of sex cycles or reproductive failure eventually. Such changes can damage the economic revenue of Lake Manzala. Thus, it is recommended to increase water circulation through inlet purgation to attenuate pollutants and restocking the lake.
\end{abstract}

\section{INTRODUCTION}

The human activities involving industry and agriculture produced tremendous amount of natural and synthetic substances such as, pesticides, herbicides, fungicides, polyaromatic, organic oxygen compounds, surfactants, drugs, metals caused disruption to physiological functions in wide variety of aquatic and terrestrial animals (Panter et al., 2006). Much can be gained by reproductive physiologists and histopathologists collaborating to better understand the effects of endocrinemodulating chemicals and other environmental stressors on reproduction and ultimately population effects on wild populations (Blazer, 2002). Some of the observations documented here, such as intersex or testis-ova and atresia, have been fairly extensively researched in terms of chemical exposures. Most reported cases 
associated with reproductive impairment in wildlife have involved aquatic organisms, particularly various species of fish (Sheahan et al., 2002).

The observed effects in fish include reduced levels of reproductive hormones (estrogens and androgens), inhibited gonadal growth, appearance of a female egg protein (vitellogenin; VTG) in male fish blood; gonadal histopathology and even intersex fish containing testis-ova or ovotestes resulted in decline in fish populations which has been observed in many parts of the world (Jobling et al., 2002, Keiter et al., 2006 and Khan, 2013).

Lake Manzala is a brackish lake in northeastern Egypt on the Nile Delta. It is the largest of the northern Delta lakes of Egypt with an area of approximately 500 $\mathrm{km}^{2}$ representing $34.2 \%$ of the total fish production of Northern natural lakes in Egypt (GAFRD, 2013; 2016). The Lake is exposed to high inputs of pollutants from industrial, domestic, and agricultural sources. Climate gases and large amounts of particulate matter, nutrients, bacteria, heavy metals, and toxic organics are transported to the Lake through the wastewater discharge (Ismail and Hettiarachchi, 2017). The Lake received about 7500 million cubic meters of untreated industrial, domestic and agricultural drainage water, discharged annually through six main drains; Bahr El-Baqer Drain, Hadous Drain, Ramsis Drain, El-Serw Drain, Matariya Drain and Faraskour Drain. This amount of wastewater was reduced to about 4000 million cubic meters after construction of El-Salam Canal (Abdel-Baky et al., 1998; El-Ghazali et al., 2015; Ismail and Hettiarachchi, 2017). The drains convey large amount of nutrients, especially from Bahr-El-Bakar, Ramsis and Hadous drains that are heavily contaminated by sewage and industrial wastewater (El-Ghazali et al., 2015). Pollution originates in urban centers such as Cairo and also along the lengths of the drains. Domestic and industrial untreated and poorly treated wastewaters are transported to Lake Manzala by the Bahr El Baqar drain over a distance of $170 \mathrm{~km}$ which dumps approximately 1.5 million $\mathrm{m}^{3} /$ day, from which 1.25 million $\mathrm{m}^{3} /$ day comes solely from Cairo governorate.

These pollutants cause decrease of species diversity; total catch and organ malformation and malfunction (Barakat et al., 2012). Thus, our performed study aimed to record the effect of the accumulated environmental pollution, which may give a glimpse of those effects and insight about the changes in fish stocks and recuperation period needed, through assessment of the reproductive health of wild Tilapia $O$. niloticus by histological studies.

\section{MATERIALS AND METHODS}

\section{Fish Sampling}

A total of 156 males and 53 females wild Oreochromis niloticus were randomly collected from Lake Manzala during the spawning season, summer of 2018. In the field, samples were manually sexed then fish total length and weight were measured and according to their weights were divide into four male and three female groups (Table 1 and 2). All fish were dissected; livers, testes and ovaries were removed and weighed to calculated both hepato-somatic index (HIS) and gonado-somatic index (GSI) as proportion of body weight.

The fish gonads were dissected and fixed in Davidson's solution, then ordinary protocol for preparing hematoxylin and eosin (H\&E) sections were done according to Fournie et al. (2000). The inspected tissue samples and testis-ova count per treatment were done in 3 replications x 5 examined fields in each slide for anomalies detection 
by a light microscope and were photographed by a fluorescence microscope Leica DM2500, Germany.

The gonadal staging for both males and females were done according to Kosai et al. (2011); male staging as follow: I- immature stage, II- early spermatogenesis, III- mid- spermatogenesis and IV- late spermatogenesis stage. While, female gonads were categories as follow: I- chromatin nucleolar stage, II- perinucleolar stage, IIIcortical alveoli formation stage, IV- vitellogenic (yolk) stage, V-ripe (mature) stage and VI- spent stage. Number of testis-ova in testicular sections and number of atretic oocytes in the ovarian sections were count in all histological specimens.

\section{Statistical Analyses}

Obtained data were subjected to one-way ANOVA followed by Duncan's multiple range test for means comparisons $(\mathrm{P}<0.05)$ using Statview 5.0 software for Windows (Abacus Concepts, Berkley, CA). All results are expressed as means \pm SE.

\section{RESULTS}

The percentage of sex ratio calculated from all caught fish was 74.64 and 25.36 for male and female, respectively. The total body length for males ranged from $11.6 \pm$ 0.18 to $19.5 \pm 0.38 \mathrm{~cm}$ and mean body weight ranged from $30.05 \pm 1.10$ to $139.73 \pm 10.15 \mathrm{~g}$ (Table 1). The gonado-somatic index (GSI) as well as hepatosomatic index data revealed significant differences among the different weight groups, the lowest GSI value obtained by G4 (0.50) and the highest was in G2 (1.26). While, the lowest value of HSI was recorded in G1 (1.46) and the highest value was in G4 (2.29).

Table 1: Male anatomical \& histological parameters, values are means $\pm \mathrm{SE}$

\begin{tabular}{|c|c|c|c|c|c|c|}
\hline Group & BW & BL & GSI & HSI & $\%$ testis-ova & Mean No. of testis-ova \\
\hline G1 & $30.05^{\mathrm{a}}$ & $11.60^{\mathrm{a}}$ & $0.57^{\mathrm{a}}$ & $1.46^{\mathrm{a}}$ & & 5.27 \\
\hline$(n=33)$ & \pm 1.10 & \pm 0.18 & \pm 0.15 & \pm 0.11 & 16.11 & \pm 1.18 \\
\hline $\mathrm{G} 2$ & $51.75^{\mathrm{b}}$ & $14.27^{\mathrm{b}}$ & $1.26^{\mathrm{b}}$ & $1.92^{\mathrm{ab}}$ & 2538 & 23.73 \\
\hline$(n=66)$ & \pm 0.88 & \pm 0.10 & \pm 0.14 & \pm 0.20 & 25.38 & \pm 10.92 \\
\hline G3 & $83.41^{\mathrm{c}}$ & $16.76^{\mathrm{c}}$ & $0.83^{\mathrm{ab}}$ & $2.4^{\mathrm{b}}$ & 3267 & 36.82 \\
\hline$(n=36)$ & \pm 1.47 & \pm 0.14 & \pm 0.11 & \pm 0.17 & $32.0 /$ & \pm 17.97 \\
\hline G4 & $139.73^{\mathrm{d}}$ & $19.50^{\mathrm{d}}$ & $0.50^{\mathrm{a}}$ & $2.29^{\mathrm{b}}$ & 4127 & 18.91 \\
\hline$(n=21)$ & \pm 10.15 & \pm 0.38 & \pm 0.11 & \pm 0.20 & 41.22 & \pm 8.95 \\
\hline
\end{tabular}

$\mathrm{n}=$ number of individuals within each group. Values with different superscript/s within each column are significantly different $(\mathrm{P}<0.05)$.

On the other hand, the females total body length was ranged from $13.6 \pm 0.29$ to $18.58 \pm 0.49 \mathrm{~cm}$ and mean body weight ranged from $39.60 \pm 1.92$ to $125.13 \pm 9.63 \mathrm{~g}$ (Table 2). The recorded GSI in the female groups showed slight changes among the weight groups; the highest value was $1.76 \pm 0.32$ obtained by G1 and the lowest value $1.31 \pm 0.30$ by G2. Akin, the HSI showed small segregation among the sampled groups, the highest record was $2.56 \pm 0.32$ in G2 and the lowest was $1.86 \pm 0.18$ in G1. However, differences of both GSI and HIS between different female groups were not significant $(\mathrm{P}>0.05)$. 
Table 2: Female anatomical \& histological parameters, values are means $\pm \mathrm{SE}$

\begin{tabular}{ccccccc}
\hline Group & BW & BL & GSI & HSI & \% Atretic oocytes & Mean No. of Atretic oocytes \\
\hline G1 & $39.60^{\mathrm{a}}$ & $13.16^{\mathrm{a}}$ & 1.76 & 1.86 & \multirow{2}{*}{1.00} & $3.82^{\mathrm{a}}$ \\
$(\mathrm{n}=22)$ & \pm 1.92 & \pm 0.29 & \pm 0.32 & \pm 0.18 & & \pm 0.52 \\
$\mathrm{G} 2$ & $63.41^{\mathrm{b}}$ & $15.56^{\mathrm{b}}$ & 1.31 & 2.56 & \multirow{2}{*}{8.93} & $10.38^{\mathrm{c}}$ \\
$(\mathrm{n}=18)$ & \pm 2.45 & \pm 0.24 & \pm 0.30 & \pm 0.32 & & \pm 0.69 \\
$\mathrm{G} 3$ & $125.13^{\mathrm{c}}$ & $18.59^{\mathrm{c}}$ & 1.66 & 2.04 & \multirow{2}{*}{3.17} & $7.19^{\mathrm{b}}$ \\
$(\mathrm{n}=13)$ & \pm 9.63 & \pm 0.49 & \pm 0.38 & \pm 0.32 & & \pm 1.14 \\
\hline
\end{tabular}

$\mathrm{n}=$ number of individuals within each group. Values with different superscript/s within each column are significantly different $(\mathrm{P}<0.05)$.

The present study showed that fish gonads were affected by the pooling of various effluents, which became evident during the microscopic inspection. The gonadal staging revealed that males showed the characteristics of sexually mature fish stage IV. Furthermore, testis-ova was detected in testicular tissue; the number and distribution of testis-ova (TO) and percentage of the influenced individuals varied among sampled groups as shown in Table 1 . Total occurrence of testis-ova among all male fish reached a percentage of $29.5 \%$. The TO manifestation showed several patterns such as, single oocyte, more than one separated oocyte, single or numerous cluster/s distributed within each microscopic field with a total average number of 20.71 (Fig. 1); in addition to, irregular shape of seminiferous tubules and vacuolation of germ cell cysts.

While, female ovaries sections showed mature stage (III) and ripping oocyte stage (IV) where detect with almost all cases and some atretic oocyte was found due to multi-group synchronous reproduction nature of tilapia (Table 2 and Fig. 2). The average number of different types of oocyte were 29.4, 13.2, 12.4, 4.8, 15.3 and 8.41 for chromatin nucleolar, perinucleolar, cortical alveoli, vitellogenic, ripe (mature) and atretic oocytes, respectively.

\section{DISCUSSION}

Histological inspection of gonadal abnormalities such TO is used to indicate the exposure to chemicals interfere with normal endocrine signaling system. The difference in the number between males and females in samples could be related to their behavior during the mating season as mentioned by Offem et al. (2007) that the cichlid populations during spawning season male tend to go for feeding areas while females reside to the protection of vegetation and rocky areas to incubate offspring and avoid predation.

The slight segregation in HIS especially in females could be related to the energy balance changes throughout the spawning season as suggested by Saeed (2013) that, it's normal response of fish at spawning and reproduction time that liver enhance the utilization of glycogen as an immediate energy source to fulfil energy demand throughout spawning seasons. The GSI also shows increase in fluctuation through the spawning season of which could be related to the asynchronous ovulation nature of female which accompanied with multi spawning events throughout the reproductive activity season. Other studies by Gerbron et al. (2014); Bertram et al. (2015) suggested that, prolonged exposure to industrial and agricultural runoff, pesticides and heavy metals can lead to deterioration of GSI through disrupting hypothalamo-gonadal axis signaling and cause temporary or permanent impairment of gonads productive and hormonal functions. 
Moreover, the found atretic oocytes in the spawning season could be associated with internal and/or external unfavorable conditions for reproduction e.g., LH surge failure, stress, low feeding intake, water quality, heavy metals and chemicals disrupting endocrine signals (Jobling et al., 1998, Pavlov et al., 2009 and Martínez, et al., 2017). The later author added that, resorption and development of a new oocytes happens simultaneously in multiple spawning fish. Hence, the female partial oocyte resorption is a physiological adaptation mechanism for a self-regulation to increase metabolism and maintain the essential reproduction status. Thomas (1989) and Banaee et al. (2008) indicated that, heavy metals, industrial and agriculture runoff have been related to several physiological alterations in fish such as, oocytes quality, vitellogenesis impairment, gonads maturation delay which eventually lead to oocyte resorption or atretic oocyte. Further, affect the hormonal path way illustrated by Nagahama (1997) and Amer et al. (2001) that illustrated the ovulatory surge of LH (GtH-II) results in a shift in steroidogenesis, which increases the production of the maturation-inducing hormone 17 $2,20 \beta$-dihydroxy-4-pregnen-3-one (17,20-DHP); action of $\mathrm{GnRH}$ is effectively blocked by $\mathrm{LH}$, which is produced in increasing amounts during late vitellogenesis. Hence, GnRH induction of apoptosis in the fish ovary which will only be possible if the ovulatory surge of LH fails to happen, due to either of inappropriate environmental cues, heavy metals or the pesticides in the environment.

The alteration caused by pesticides, heavy metals and other accumulated pollutants to the testicular architecture had suppressed the spermatogenesis; as well as, the presence of testis-ova displayed the seriousness of pollutants influence on male testis. As reported by other scholars such as Johnson et al. (2009), Kosai et al. (2011), Sadekarpawar and Parikh (2013), Dhanasekar et al. (2018) that due to the dynamic of testes and high cell turnover its more vulnerable to a wide variety of chemical toxicants that elevated the occurrence of intersex in wild fish populations associated with exposure to human wastewater. Furthermore, Bin-Dohaish (2012) and Adeogun et al. $(2018 ; 2019)$ mentioned that, synthetic products such as biphenol A, polychlorinated biphenol, dioxins, phtalates, pesticides, heavy metals, alkyphenols, polycyclic aromatic hydrocarbons, ethinylestradiol and estradiol. Such compounds, among others, that seeping from sewage water to aquatic environments are associated with observation of testis-ova in males and changes in secondary sex characteristics of male and female fish.

\section{CONCLUSION}

The data reflected the prominent changes in the males and females gonadal structure, which could be attributed to the accumulation of pollutants and prolonged period of exposure. This may affect the future spawning seasons; the rate of sex cycles or reproductive failure sooner or later. Such changes can damage the economic revenue of Lake Manzala.

From these results fish could be used as biological indicator for detecting surface water pollutants existed by various effluents. In addition to include the histological findings of gonads as a routine qualitative diagnostic tool to assess the reproductive quality or potency of individuals. As a recommendation, increasing the water circulation through inlet purgation and constructing new feeding inlets and water treatment plants to attenuate pollutants and restocking the lake. As well as, making radial canals to allow recovery of physical, chemical, and biological status of a lake. 


\section{REFERENCES}

Abdel-Baky, T. E.; Hagras, A.E.; Hassan, S.H. and Zyadah, M.A (1998). Environmental impact assessment of pollution in Lake Manzalah, 1Distribution of some heavy metals in water and sediment. J. Egypt. Ger. Soc. Zool., 26(B): 25-38.

Adeogun, A.O.; Ibor, O.R.; Chukwuka, A.V.; Regoli, F. and Arukwe, A. (2019). The intersex phenomenon in Sarotherodon melanotheron from Lagos lagoon (Nigeria): Occurrence and severity in relation to contaminants burden in sediment. Environmental Pollution, 244: 747-756.

Adeogun, A.O.; Ibor, O.R.; Imiuwa, M.E.; Omogbemi, E.D.; Chukwuka, A.V., Omiwole, R.A. and Arukwe, A. (2018). Endocrine disruptor responses in African sharp tooth catfish (Clarias gariepinus) exposed to di-(2-ethylhexyl)phthalate. Comparative Biochemistry and Physiology, 213(C): 7-18.

Amer, M.A.; Miura, T.; Miura, C. and Yamauchi, K. (2001). Involvement of Sex Steroid Hormones in the Early Stages of Spermatogenesis in Japanese Huchen (Hucho perryi). Biology of Reproduction, 65: 1057-1066.

Banaee, M.; Mirvagefei, A.R.; Rafei, G.R. and Amiri, B.M. (2008). Effect of sublethal Diazinon Concentrations on Blood Plasma Biochemistry. International Journal of Environmental Research, 2(2): 189-198.

Barakat, A.O.; Mostafa, A.; Wade, T.L.; Sweet, S.T. and El Sayed, N.B. (2012). Assessment of persistent organochlorine pollutants in sediments from Lake Manzala, Egypt. Marine Pollution Bulletin, 64: 1713-1720.

Bertram, M.G.; Saaristo, M.; Baumgartner, J.B.; Johnstone, C.P.; Allinson, M.; Allinson, G. and Wong, B.B. (2015). Sex in troubled waters: widespread agricultural contaminant disrupts reproductive behavior in fish. Horm., Behav., 70: 85-91.

Bin-Dohaish, E.A. (2012). The effects of 4-nonylphenol contamination on livers of Tilapia fish (Oreochromus spilurs) in Jeddah. Biol. Res., 45: 15-20.

Blazer, V.S. (2002). Histopathological assessment of gonadal tissue in wild fishes. Fish Physiology and Biochemistry, 26: 85-101.

Dhanasekar, K.; Selvakumar, N. and Munuswamy, N. (2018). Occurrence of Intersex in Grey Mullet, Mugil cephalus L. from Kovalam Coast, Tamil Nadu. Turkish Journal of Fisheries and Aquatic Sciences, 18: 603-609.

El-Ghazali, A.M.; Amer, A.A. and Mustafa, M.M. (2015). Proposed Decision Support System for Reduction of Total Phosphorus in Lake Manzala. Egyptian Computer Science Journal, 39(4): 56-70.

Fournie, J.W.; Krol, R.M. and Hawkins, W.E. (2000). Fixation of fish tissues. In: "The laboratory fish". Ostrander, G.K. (Ed.)., Academic Press, N.Y, pp. 569578.

GAFRD (2013). The General Authority for fish Resources Development, Lake Manzala article, http://www.gafrd.org/posts/84846

GAFRD (2016). The General Authority for fish Resources Development, Fish Statistics year Book.

Gerbron, M.; Geraudie, P.; Fernandes, D.; Rotchell, J.M.; Porte, C. and Minier, C. (2014). Evidence of altered fertility in female roach (Rutilus rutilus) from the River Seine (France). Environ. Pollut., 191: 58-62.

Ismail, A. and Hettiarachchi, H. (2017). Environmental Damage Caused by Wastewater Discharge into the Lake Manzala in Egypt. American Journal of Bioscience and Bioengineering, 5(6): 141-150. 
Jobling, S.; Nolan, M.; Tyler, C.B.; Brighty, G. and Sumpter, J.P. (1998). Widespread sexual disruption in wild fish. Environ. Sci. Technol., 32: 2498-2506.

Johnson R.; Wolf, J. and Braunbeck, T. (2009). OECD Guidance Document for the Diagnosis of Endocrine-Related Histopathology of Fish Gonads, pp. 96.

Keiter, S.; Rastall, A.; Kosmehl, T.; Wurm, K.; Erdinger, L.; Braunbeck, T. and Hollert, H. (2006). Ecotoxicological assessment of sediment, suspended matter and water samples in the upper Danube River: a pilot study in search for the causes for the decline of fish catches. Environmental Science and Pollution Research, 13: 308-319.

Khan, R.A. (2013). Effects of Polycyclic Aromatic Hydrocarbons on Sexual Maturity of Atlantic cod, Gadus morhua, Following Chronic Exposure. Environment and Pollution, 2 (1): http://dx.doi.org/10.5539/ep.v2n1p1.

Kosai, P.; Jiraungkoorskul,W.; Sachamahithinant, C. and Jiraungkoorskul, K. (2011). Induction of testis-ova in Nile tilapia (Oreochromis niloticus) exposed to $17 \beta$ estradiol. Natural Science, 3(3): 227-233.

Martínez, A.T.; Sánchez, A.J.; Pliego, N.A.; Franyutti, A.A.H.; Hernández, J.C.L. and Regil, J.B. (2017). Gonadal Histopathology of Fish from La Pólvora Urban Lagoon in the Grijalva Basin, Mexico. Int. Contam. Ambie., 33(4): 713-717.

Nagahama, Y. (1997). 17 $\alpha$, 20ß-Dihydroxy-4-pregnen-3-one, a maturation inducing hormone in fish oocytes: mechanisms of synthesis and action. Steroids, 62:190196.

Offem B.O.; Akegbejo-Samsons, Y. and Omoniyi, I.T. (2007). Biological assessment of Oreochromis niloticus (Pisces: Cichlidae; Linne, 1958) in a tropical floodplain river. African J. Biotechnol., 6 (16): 1966-1971.

Panter, G.H.; Hutchinson, T.H.; Hurd, K.S.; Bamforth, J.; Stanleya, R.D.; Duffell, S.; Hargreaves, A.; Gimeno, S. and Tyler, C.R. (2006). Development of chronic tests for endocrine active chemicals Part 1 . An extended fish early-life stage test for oestrogenic active chemicals in the fathead minnow (Pimephales promelas). Aquatic Toxicology, 77: 279-290.

Pavlov, D.A.; Emel'yanova, N.G. and Novikov, G.G. (2009). Reproductive Dynamics. In: "Fish Reproductive Biology, Implications for Assessment and Management". Tore Jakobsen, T.; Fogarty, M.J.; Megrey, B.A. and Moksness, E. (Eds.). Wiley-Blackwell, Blackwell Publishing Ltd., U.K., pp. 48-90.

Sadekarpawar, S. and Parikh, P. (2013). Gonadosomatic and Hepatosomatic Indices of Freshwater Fish Oreochromis mossambicus in Response to a Plant Nutrient. World Journal of Zoology, 8 (1): 110-118.

Saeed, S.M. (2013). Impact of environmental parameters on fish condition and quality in Lake Edku, Egypt. Egypt. J. Aquat. Biol. \& Fish., 17(1): 101-112.

Sheahan, D.A.; Brighty, G.C.; Daniel, M. Kirby, S.J.; Hurst, M.R.; Kennedy, J.; Morris, S.; Routledge, E.J.; Sumpter, J.P. and Waldock, M.J. (2002). Estrogenic activity measured in a sewage treatment works treating industrial inputs containing high concentrations of alkylphenolic compounds a case study. Environ. Toxicol. Chem., 21: 507-514.

Thomas, P. (1989). Effects of Aroclor 1254 and cadmium on reproductive endocrine function and ovarian growth in Atlantic croaker. Marine Environmental Research, 28: 499-503. 

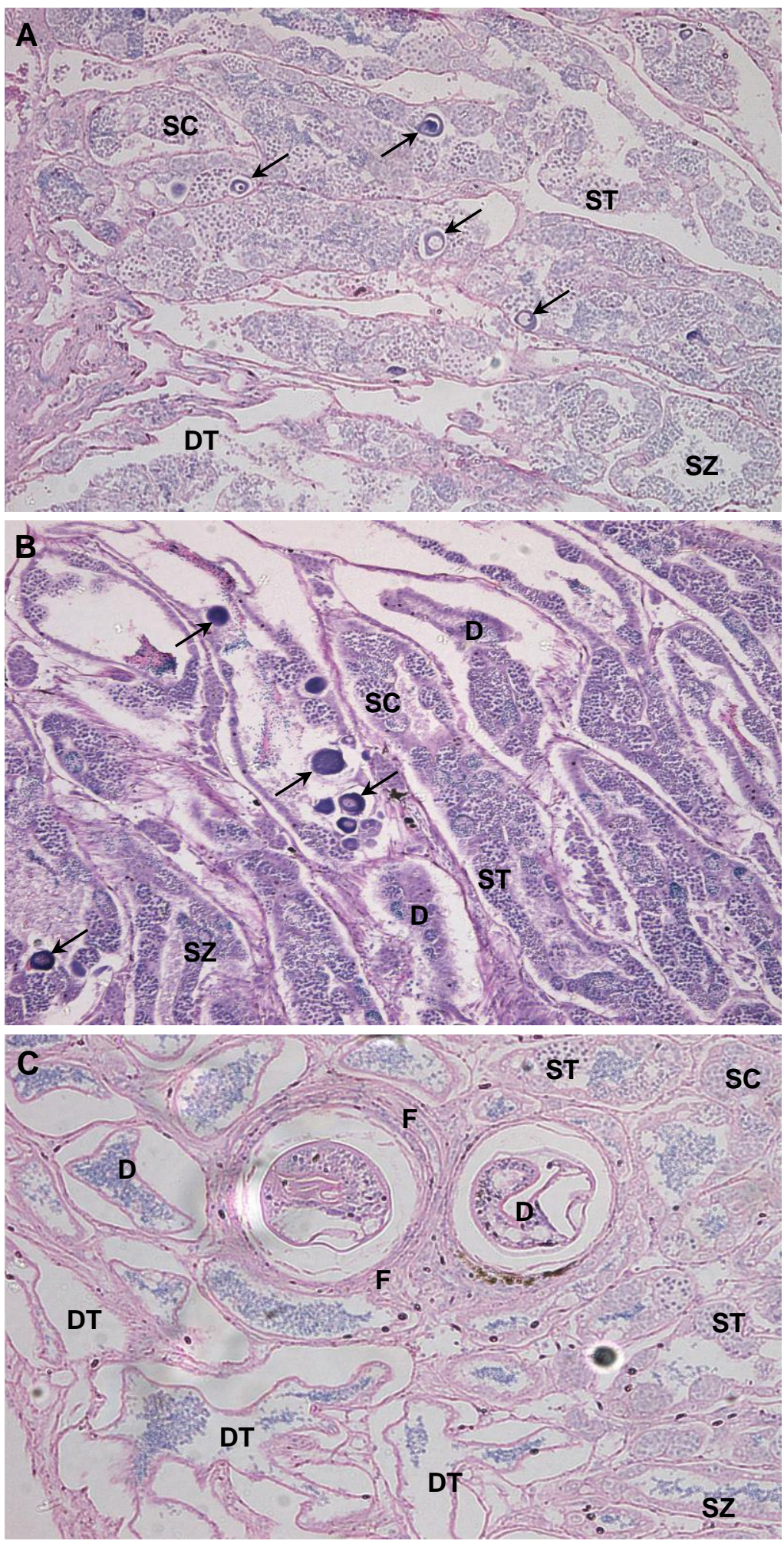

Fig. 1: Histological sections of $O$. niloticus testes showed different stages of spermatogenesis (A-C) x100. All types of spermatogenetic cysts appeared including SC-spermatocytes, ST-spermatids and SZ- spermatozoa. Spermatid cysts are the most occurrence type of spermatogenetic cysts in testicular sections (A\&B). Deterioration (DT), degeneration (D) and fibrosis (F) of testicular lobules and germinal epithelium are pronounced especially in B and C. Individual or nests of testis-ova (arrows) are distributed in all testicular sections indicating the adverse effect of pollutants on testis structure. 

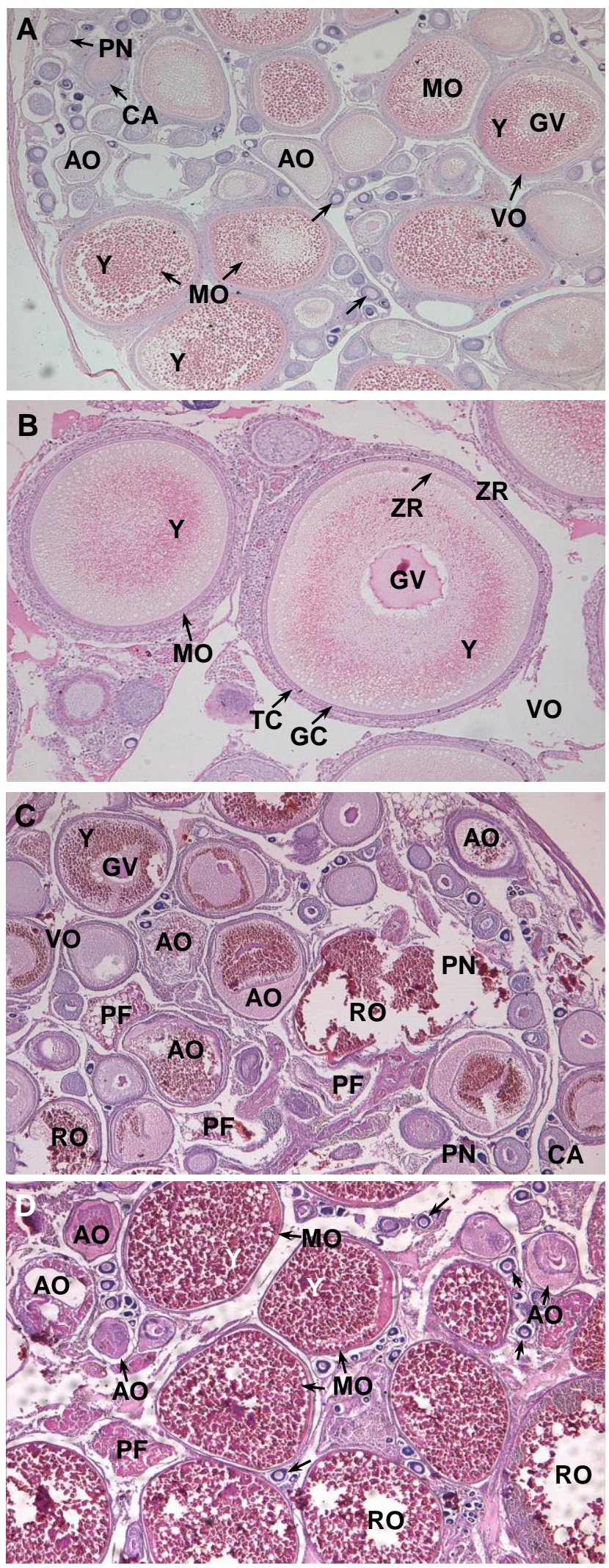

Fig. 2: Histological sections (A-D) x40 of O. niloticus ovaries illustrated oocytes in different developmental stages: I- Chromatin nucleolar stage (arrows), II- Perinucleolar stage (PN), IIICortical alveoli stage (CA), IV- Vitellogenic oocyte stage (VO) and V- Mature (ripe) oocyte stage (MO). AO- atretic oocytes, RO-reabsorbed oocytes, PF-postovulatory follicle, Y-yolk, GV-germinal vesicle (nucleus), ZR-zona radiata, GL-granulosa cells layer, and TL-theca cell layer. In mostly all examined ovarian sections, oocytes during early stages appeared normally, however, atretic and reabsorbed oocytes were observed in vitellogenic and mature stages. 


\section{ARABIC SUMMARY}

\section{التقييم النسيجي للغذد التناسلية لأسماك البلطي النيللى البرية ببحيرة المنزلة، مصر.}

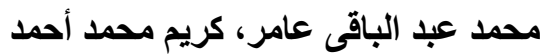

قسم الإنتاج الحيو انى، كلية الزراعة ـ جامعة عين شمس، القاهرة، مصر

الهدف من هذه الدراسة هو اكتشاف الآثار الضارة لملوثات المياه على شكل وتركيب الغدد التناسلية

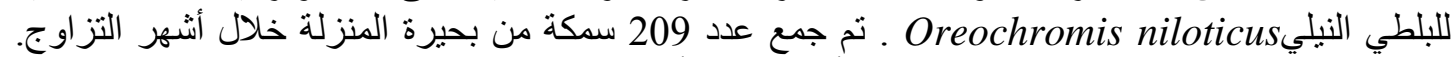

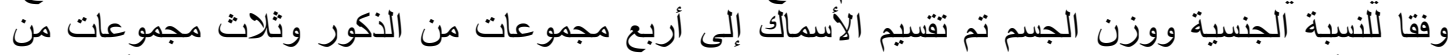

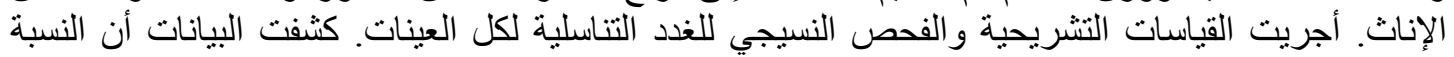

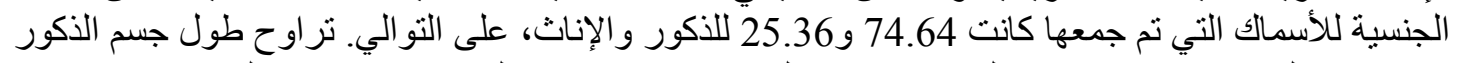

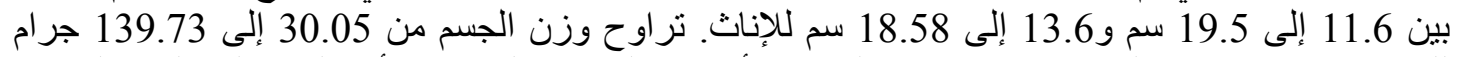

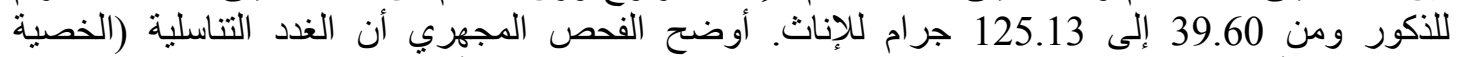

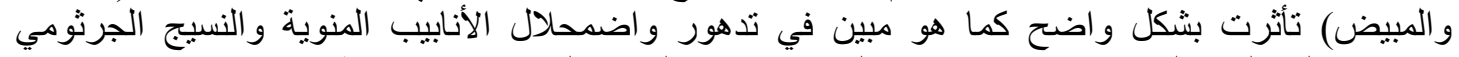

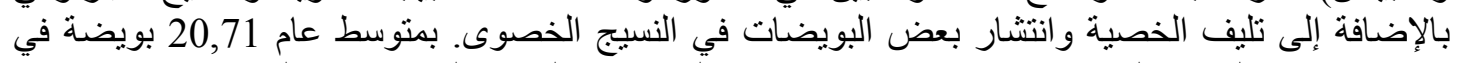

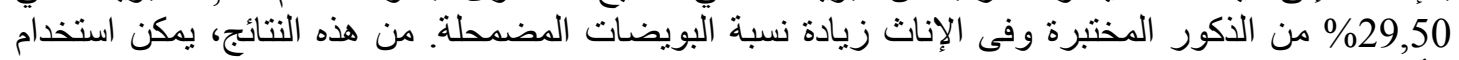

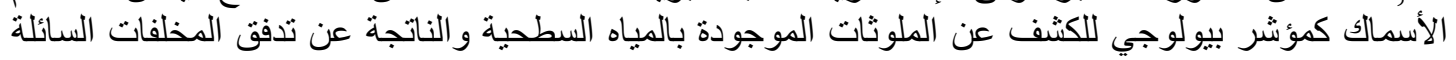

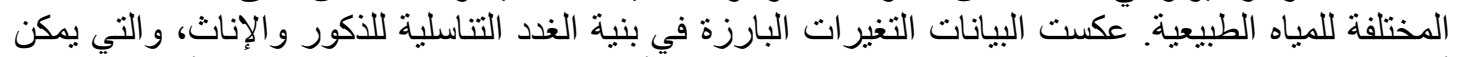

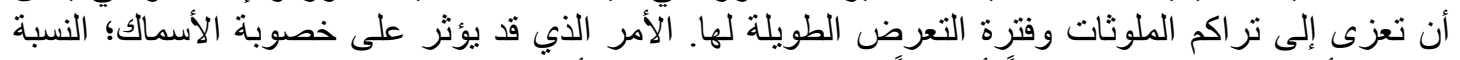

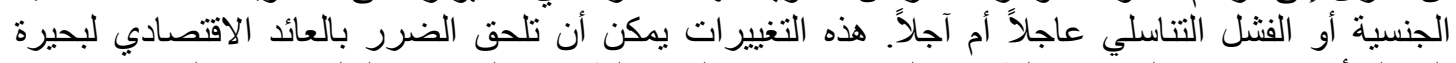

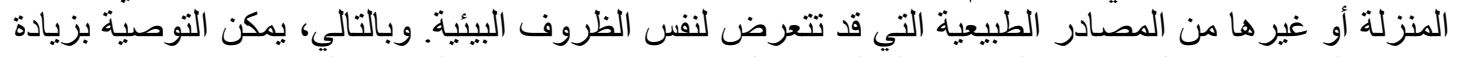

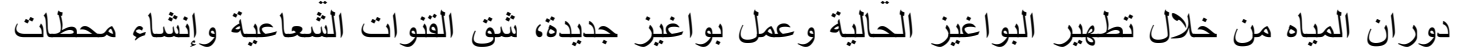
معالجة المياه لتخفيف حدة الملوثات بالبحيرة. 